\title{
Successful Endoscopic Dilation Treatment of Small Intestinal Stricture Occurring during Chemotherapy for Malignant Lymphoma
}

\author{
Yusuke Honzawa ${ }^{a}$ Masahiko Kondo ${ }^{b}$ \\ Takanobu Hayakumo $^{\mathrm{b}}$ Minoru Matsuura ${ }^{\mathrm{a}}$ Hiroshi Nakase $^{\mathrm{a}}$ \\ aDepartment of Gastroenterology and Hepatology, Graduate School of Medicine, \\ Kyoto University, Kyoto, and ' ${ }^{\circ}$ epartment of Gastroenterology, Otsu Red Cross \\ Hospital, Otsu, Japan
}

\section{Key Words}

Malignant lymphoma - Endoscopic balloon dilation - Stricture

\begin{abstract}
We report a stricture occurring during chemotherapy for malignant lymphoma that was successfully treated by endoscopic balloon dilation. The patient was diagnosed with stage IV malignant lymphoma by esophagogastroduodenoscopy and computed tomography scans. She complained of nausea and vomiting after undergoing the second cycle of chemotherapy. A small intestinal series through an ileus tube showed severe stricture of the ileum. Endoscopic balloon dilation was successfully performed with single-balloon endoscopy. After the procedure, her symptoms subsided and did not recur even 8 months after endoscopic dilation therapy.
\end{abstract}

\section{Introduction}

Intestinal stricture is a major complication that may occur during or after chemotherapy for gastrointestinal lymphoma. Symptomatic strictures usually require surgical resection of the intestine $[1,2]$. The recently developed technique of balloon endoscopy allows for diagnosis of small intestinal lesions as well as for performing several endoscopic therapies, such as balloon dilation of small intestinal stenosis in Crohn's disease [3-5]. Here, we report a case in whom endoscopic dilation under balloon endoscopy was very useful for treating a stricture of the small intestine that occurred during chemotherapy for malignant lymphoma. 


\begin{tabular}{r|l|l|l} 
Case Reports in & $\begin{array}{l}\text { Case Rep Gastroenterol 2010;4:323-329 } \\
\text { DOI: 10.1159/000320538 }\end{array}$ & $\begin{array}{l}\text { Published online: } \\
\text { September 11, 2010 }\end{array}$ & $\begin{array}{l}\text { ISSN 1662-0631 } \\
\text { www.karger.com/crg }\end{array}$ \\
Gastuelteroloyy & &
\end{tabular}

\section{Case Report}

A 78-year-old woman presented at our hospital with complaints of loss of appetite for 6 months. On admission, she appeared undernourished (height $159.5 \mathrm{~cm}$, weight $45.5 \mathrm{~kg}$ ), and had a regular pulse rate of 91 beats per minute, a blood pressure of $129 / 51 \mathrm{~mm} \mathrm{Hg}$, and a temperature of $37.7^{\circ} \mathrm{C}$. Physical examination revealed enlarged lymph nodes in the cervical, axillary, and supraclavicular regions and conjunctival anemia. Laboratory data were as follows: white blood cell count 9,500/ $\mu \mathrm{l}$ (normal 3,5007,000 ), hemoglobin $8.7 \mathrm{~g} / \mathrm{dl}$ (normal 11.7-15.8), platelets $18.1 \times 10^{4} / \mu \mathrm{l}$ (normal $14.0-35.0 \times 10^{4}$ ), lactate dehydrogenase $533 \mathrm{IU} / \mathrm{l}$ (normal 80-230), total protein $5.1 \mathrm{~g} / \mathrm{dl}$ (normal 6.0-8.0), albumin $2.9 \mathrm{~g} / \mathrm{dl}$ (normal 4.0-5.0), C-reactive protein $2.4 \mathrm{mg} / \mathrm{dl}$ (normal 0.0-0.5), ferritin $602 \mathrm{ng} / \mathrm{ml}$ (normal 3.6-114.0), soluble interleukin 2 receptor $8,100 \mathrm{U} / \mathrm{ml}$ (normal 145-519). Esophagogastroduodenoscopy revealed an irregular ulcer at the greater curvature of the lower gastric body. Histologic examination of biopsy specimens showed a diffuse infiltrate of lymphoid cells. Immunohistochemically, neoplastic lymphoid cells were positive for CD20, but negative for CD3. Computed tomography (CT) scans showed systemic lymph node enlargement and increased gastric and distal ileal wall thickness (fig. 1a).

Based on these findings, she was diagnosed with stage IV diffuse large B-cell lymphoma. She was admitted to our hospital for chemotherapy (rituximab, cyclophosphamide, hydroxydaunorubicin, vincristine, and prednisolone [R-CHOP] regimen). After the second cycle of chemotherapy, she complained of abdominal pain and vomiting. CT scans showed dilation of the small intestine (fig. 1b). An ileus tube was inserted and a small intestinal series through the ileus tube showed severe stenosis of the ileum approximately $50 \mathrm{~cm}$ proximal to the ileocecal valve (fig. 2 ). We considered it necessary to treat this small intestinal stricture as quickly as possible because the patient required additional chemotherapy for swelling of abdominal lymph nodes suggestive of residual lymphoma. After informed consent was obtained from the patient and her family, we performed endoscopic dilation therapy with a single-balloon endoscopy (SIF-Q260; Olympus Co., Ltd, Tokyo, Japan). The balloon catheter was inserted into the stenotic site through the scope channel (fig. $3 \mathrm{a}-\mathrm{c}$ ). The maximum pressure of the balloon was controlled using a monitor. The balloon was only dilated up to $9 \mathrm{~mm}$ in diameter and dilation time was only $60 \mathrm{~s}$ because the patient complained of mild abdominal pain when the balloon diameter reached $9 \mathrm{~mm}$. After this procedure, fluoroscopy showed successful dilation (fig. 3c) and chemotherapy was resumed after three days. Eight months after this procedure, her symptoms had not recurred and 6 cycles of chemotherapy were uneventfully performed, resulting in complete disease remission.

\section{Discussion}

This is a case of successful treatment with endoscopic balloon dilation for a small intestinal stricture that occurred during chemotherapy for malignant lymphoma. Most small intestinal strictures resulting from chemotherapy of malignant lymphoma are treated surgically because of the risk of perforation [6]. In this case, however, the patient still required additional chemotherapy for residual malignant lymphoma when the stricture of the small intestine appeared. Therefore, instead of surgical treatment, we selected endoscopic balloon dilation therapy so that R-CHOP could be continued with minimal interruption. As a result, the patient was able to resume chemotherapy immediately after endoscopic balloon dilation and achieved clinical remission.

Endoscopic balloon dilation is considered a standard therapy for strictures related to inflammatory lesions and anastomotic strictures of the large and small intestine [7, 8]. In particular, a significant proportion of patients with Crohn's disease develop strictures that result in recurrent obstructive symptoms. Therefore, most symptomatic patients with Crohn's disease require further intervention, either surgery or endoscopic dilation. Of these treatment options, balloon dilation has the advantage of being safe and to preserve intestinal length. Thus, endoscopic dilation therapy is an established treatment for patients with Crohn's disease who have stenotic symptoms. Whether endoscopic dilation 


\begin{tabular}{|c|c|c|c|}
\hline $\begin{array}{l}\text { Case Reports in } \\
\text { Gastrualterolouy }\end{array}$ & $\begin{array}{l}\text { Case Rep Gastroenterol 2010;4:323-329 } \\
\text { DOI: } 10.1159 / 000320538\end{array}$ & $\begin{array}{l}\text { Published online: } \\
\text { September 11, } 2010\end{array}$ & \begin{tabular}{|l} 
@ 2010 S. Karger AG, Basel \\
ISSN 1662-0631 \\
www.karger.com/crg
\end{tabular} \\
\hline
\end{tabular}

therapy is safe and applicable for intestinal strictures related to malignant lymphoma that occur during or after chemotherapy remains unclear, however, because of the very few number of cases reported.

We have summarized four cases in which endoscopic dilation therapy was used for intestinal strictures related to malignant lymphoma, including the present case (table 1 ) [9]. In three of the four cases (75\%), successful endoscopic dilation therapy was performed without complication, and perforation occurred in the other case.

Coumaros et al. reported that balloon dilation through a scope using double-balloon endoscopy is likely to be a useful palliative treatment option for otherwise difficult to manage small intestinal strictures complicating lymphoma patients [10]. In the present case, the small intestinal stricture occurred during chemotherapy, which is different from the other cases in whom the strictures occurred after chemotherapy. Generally, intestinal stricture related to malignant lymphoma is considered to be more fragile than that of non-malignant lesions such as Crohn's disease. Therefore, prior to dilation therapy for intestinal stricture related to malignant lymphoma, we deliberately evaluate whether or not residual tumor exists at the stenotic site for which dilation therapy would be performed. In the present case, both endoscopic and CT findings demonstrated no visible tumor at the stenotic site, suggesting that this stenotic lesion was indicated for dilation therapy. However, we should keep in mind performing it for intestinal stenosis related to malignant lymphoma more deliberately than for that of Crohn's disease.

Although surgical treatment might have been an option for this patient, the patient could not have undergone additional chemotherapy for the residual malignant lymphoma immediately after the treatment. Thus, in this case, endoscopic, although maybe only palliative therapy, was considered.

Cho et al. [6] reported a case of perforation after endoscopic balloon dilation for an intestinal stricture of malignant lymphoma, in whom perforation occurred at the second trial of the dilation therapy 14 months after the first dilation therapy. Their case report suggested some clinically important points. First, an intestinal stricture related to malignant lymphoma can recur, similar to that in patients with Crohn's disease, after dilation therapy. Patients with lymphoma whose intestinal strictures are treated by endoscopic dilation therapy should therefore be carefully followed up. In addition, because repeated dilation therapy with increased balloon dilation size for intestinal stricture could increase the risk of perforation, examination with endoscopic ultrasonography before dilation therapy to check the status of the wall structure may be necessary.

The extent of an intestinal stricture dilated safely by endoscopic therapy as well as the size of dilation safely performed is unclear at present. In our case, we dilated the stricture up to only $9 \mathrm{~mm}$ due to complaints of abdominal pain by the patient during dilation therapy and finished only $60 \mathrm{~s}$. The patient's stenotic symptoms were ameliorated, however, and subsequent chemotherapy was uneventfully performed, resulting in disease remission. Thus, the goal of dilation therapy is not excessive dilation but sufficient dilation to relieve the patient's symptoms.

In conclusion, the present case report supports the usefulness of endoscopic dilation therapy for intestinal stricture related to malignant lymphoma. Careful consideration of the cases indicated for endoscopic dilation therapy, however, is necessary. 
Table 1. Details of balloon dilation for the stricture of malignant lymphoma in the reported cases

\begin{tabular}{lllllll}
\hline Case & Age/sex & Classification & Staging & $\begin{array}{l}\text { Site of } \\
\text { stricture }\end{array}$ & $\begin{array}{l}\text { Balloon } \\
\text { diameter }\end{array}$ & Result \\
\hline 1 & $75 /$ man & unknown & stage IV & terminal ileum & $18 \mathrm{~mm}$ & perforation \\
\hline 2 & $48 /$ woman & $\begin{array}{l}\text { diffuse large } \\
\text { B-cell lymphoma }\end{array}$ & stage IV & jejunum & $15 \mathrm{~mm}$ & success \\
\hline 3 & $74 /$ woman & follicular lymphoma & stage IV & jejunum & unknown & success \\
\hline $\begin{array}{l}\text { Our } \\
\text { case }\end{array}$ & $78 /$ woman & $\begin{array}{l}\text { diffuse large } \\
\text { B-cell lymphoma }\end{array}$ & stage IV & ileum & $9 \mathrm{~mm}$ & success \\
\hline
\end{tabular}
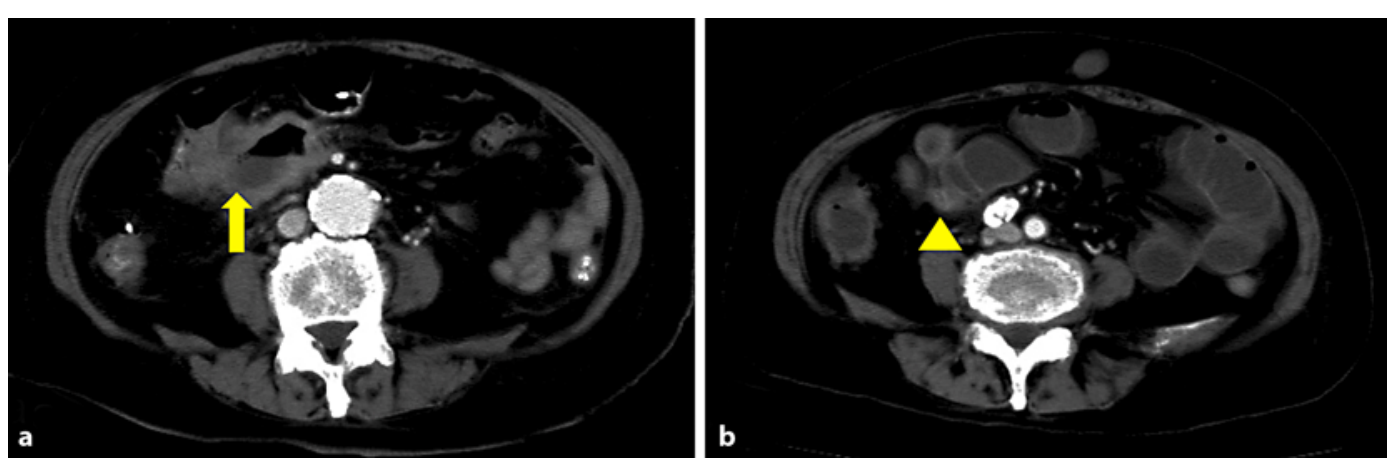

Fig. 1. a CT scan showing distal ileum wall thickness (yellow arrow). b Contrast-enhanced CT scan of the abdomen after the second cycle of chemotherapy showed dilation of the ileum (yellow arrowhead). 


\begin{tabular}{r|l|l|l}
$\begin{array}{r}\text { Case Reports in } \\
\text { Gastruanterology }\end{array}$ & $\begin{array}{l}\text { Case Rep Gastroenterol 2010;4:323-329 } \\
\text { DOI: 10.1159/000320538 }\end{array}$ & $\begin{array}{l}\text { Published online: } \\
\text { September 11, 2010 }\end{array}$ & $\begin{array}{l}\odot \text { 2010 S. Karger AG, Basel } \\
\text { ISSN 1662-0631 } \\
\text { www.karger.com/crg }\end{array}$ \\
\hline
\end{tabular}

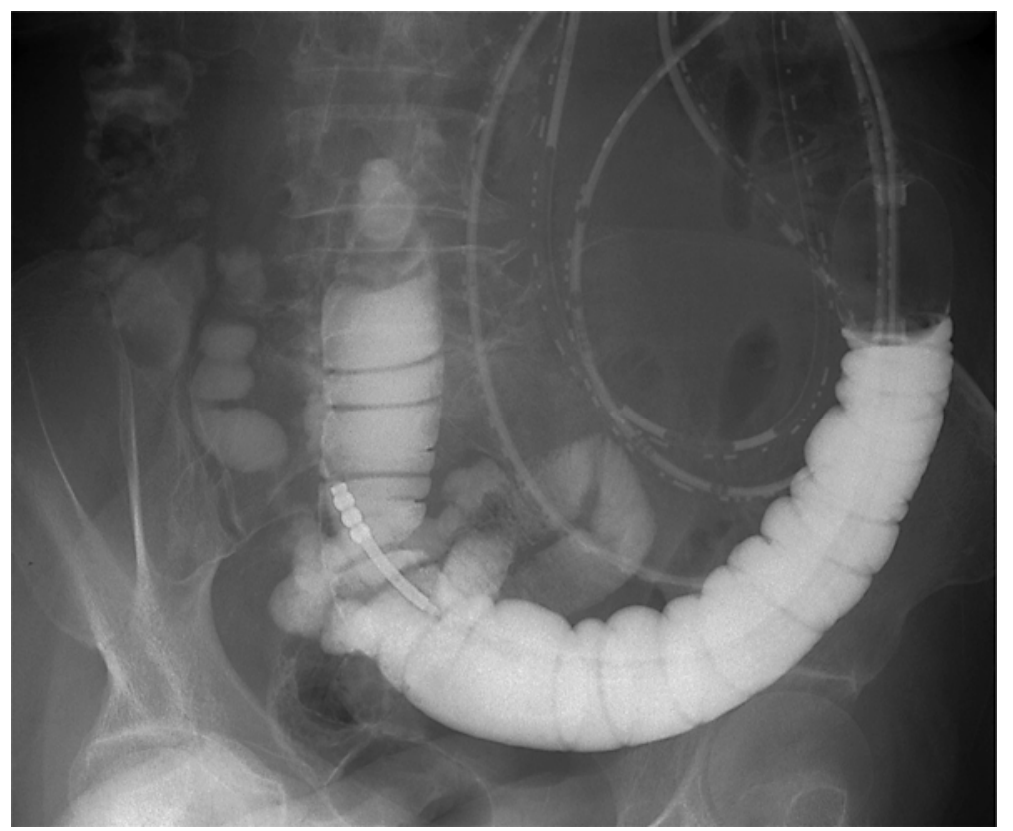

Fig. 2. Small intestinal series through the ileus tube showing severe stenosis of the ileum approximately $50 \mathrm{~cm}$ proximal to the ileocecal valve. 


\begin{tabular}{r|l|l|l} 
Case Reports in & $\begin{array}{l}\text { Case Rep Gastroenterol 2010;4:323-329 } \\
\text { DOI: 10.1159/000320538 }\end{array}$ & $\begin{array}{l}\text { Published online: } \\
\text { September 11, 2010 }\end{array}$ & $\begin{array}{l}\odot \text { 2010 S. Karger AG, Basel } \\
\text { ISSN 1662-0631 } \\
\text { www.karger.com/crg }\end{array}$ \\
\hline
\end{tabular}
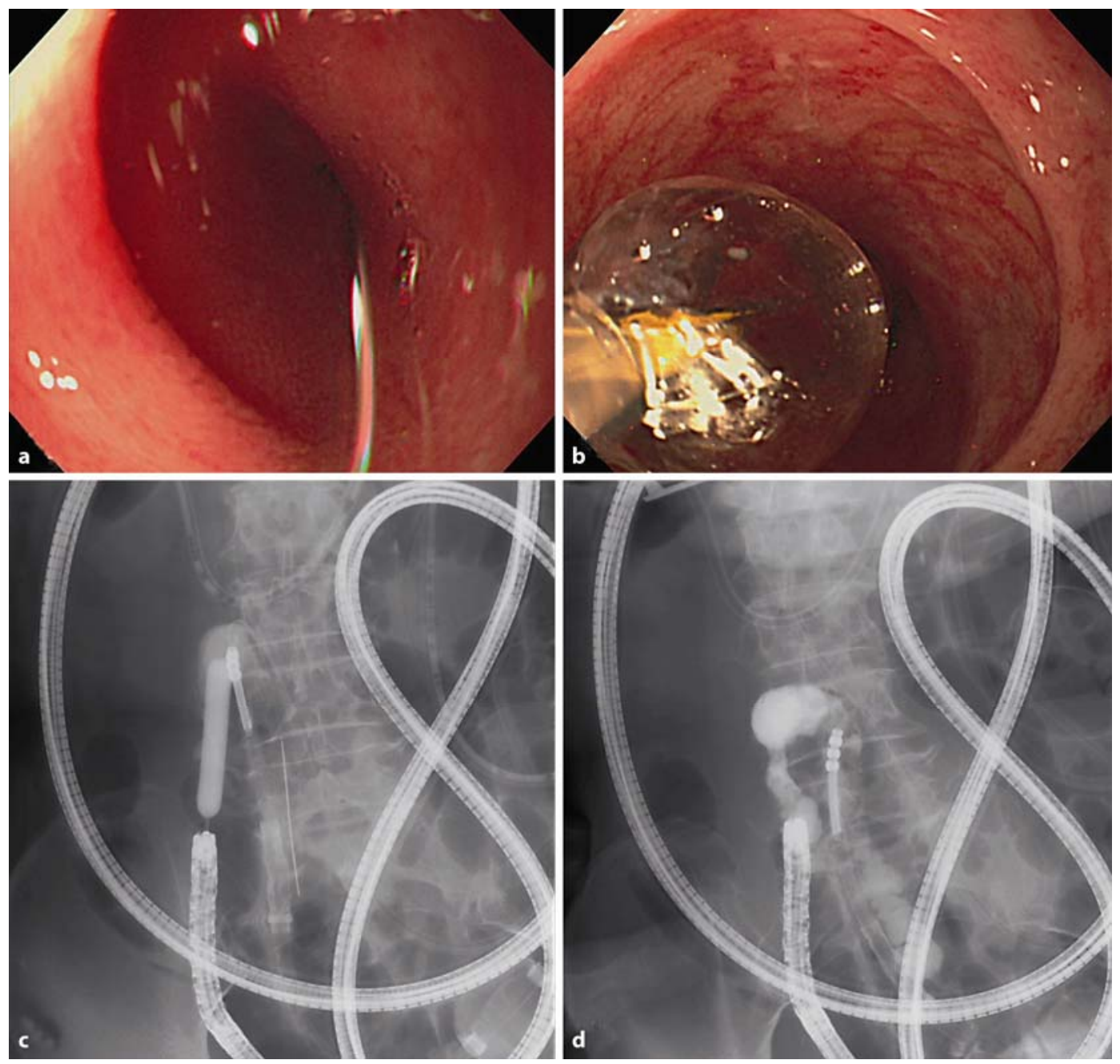

Fig. 3. Endoscopic findings of balloon dilation and dilation balloon under fluoroscopy. a Ileal stenosis. b Dilated balloon. c Dilated balloon under fluoroscopy. d Dilated stricture in malignant lymphoma under fluoroscopy.

\section{References}

1 Maeda K, Hanai T, Katuno H, et al: Surgical treatment of malignant lymphoma in the intestine. Stom Intest 2006;41:356-362.

2 Bo L, Yuan-Kai S, Li-Yan X, et al: Primary non-Hodgkin lymphomas in the small and large intestine: clinicopathological characteristics and management of 40 patients. Int J Hematol 2008;87:375-381.

-3 Almeida N, Figueiredo P, Leitão MC: Double-balloon enteroscopy and small bowel tumors: a south-European single-center experience. Dig Dis Sci 2009;54:1520-1524.

-4 Stanislav R, Ilja T, Jan B, et al: Interventional double balloon endoscopy for Crohn's, gastrointestinal bleeding, and foreign body extraction. Tech Gastrointest Endosc 2008;10:101-106.

5 Mitsui K, Tanaka S, Sakamoto C, et al: Role of double balloon endscopy in the diagnosis of small-bowel tumor: the first Japanese multicenter study. Gastrointest Endosc 2009;70:498-504.

6 Cho E, Uno K, Nakajima M, et al: A case with perforation after endoscopic balloon dilatation for stricture of malignant lymphoma. Digest Endosc 2004;16:s73-s75. 
7 Sunada K, Yamamoto H, Mizuta K, et al: Clinical outcomes of enteroscopy using the double-balloon method for strictures of the small intestine. World J Gastroenterol 2005;11:1087-1089.

8 Haruta H, Yamamoto H, Mituki K, et al: A case of successful enteroscopic balloon dilation for late anastomotic stricture of choledochojejunostomy after living donor liver transplantation. Liver Transpl 2005;11:1608-1610.

$\$ 9$ Tamura H, Ogata Y, Dan K, et al: Double balloon endoscopy as a useful tool for the diagnosis and treatment of four cases of primary small intestinal lymphoma. Jpn J Clin Hematol 2007;48:510-513.

10 Coumaros D, Tsesmeli N, Tzilves D: Diffuse large B-cell lymphoma complicated with jejunal stricture: the palliative role of double-balloon enteroscopy. Am J Gastroenterol 2008;103:2656-2657. 